\title{
Valorization of Superabsorbent Polymers from Used Disposable Diapers as Soil Moisture Conditioner
}

\author{
Raymundo Sánchez-Orozco ${ }^{1, *}$, Beatriz Timoteo-Cruz ${ }^{1}$, Teresa Torres-Blancas ${ }^{2}$ and Fernando Ureña- \\ Núñez ${ }^{3}$ \\ 1 Laboratorio de Química Aplicada, Tecnológico de Estudios Superiores de Jocotitlán, Jocotitlán, Estado de \\ México C.P. 50700, México; r.sanchez@tesjo.edu.mx (R.S-O.);_play_bty@hotmail.com (B.T-C) \\ 2 Centro Conjunto de Investigación en Química Sustentable UAEMéx-UNAM, Instituto de Química, \\ Universidad Nacional Autónoma de México, Toluca, Estado de México C.P. 50200, México; \\ thereza_btt@yahoo.com.mx \\ 3 Instituto Nacional de Investigaciones Nucleares, Apartado Postal 18-1027, Col. Escandón, México D.F. C.P. \\ 11801, México; fernando.urena@inin.gob.mx \\ * Correspondence: r.sanchez@tesjo.edu.mx; Tel.: +52-712-123-1313
}

\begin{abstract}
This study was conducted to explore the potential of superabsorbent polymers (SAPs) from used disposable diapers as soil moisture conditioner. Swelling behavior of the proposed hydrogel in response to external stimuli such as salt solutions, temperature and $\mathrm{pH}$ was studied. In addition, laboratory experiments were carried out to evaluate the effects of incorporation hydrogel on germination of bean (Phaseolus vulgaris L.) and pumpkin (C. pepo) seeds. The structure of the superabsorbent was characterized by Fourier transform infrared spectroscopy (FTIR). The results indicate that the proposed SAP exhibited a maximum swelling capacity of $189 \mathrm{~g} \cdot \mathrm{g}^{-1}$ of dry gel. It was observed that the swelling capacity decreased with an increase in the ionic strength of the swelling medium. When this SAP was mixed with sandy soil, the mixture was able to lose water more slowly. The seeds germination and seedling growth was remarkably influenced by the application of $0.5,1.0$ and $2.0 \mathrm{w} / \mathrm{w} \%$ of SAP compared to the untreated soil. Therefore, it follows that it is possible to take advantage of SAPs property from used disposable diapers to retain the moisture in soil as an alternative to value the use of such waste, showing that it has potential for diverse applications in agriculture.
\end{abstract}

Keywords: used superabsorbent polymer; disposable diapers; swelling capacity; soil conditioner

\section{Introduction}

One of the most alarming problems in the world today is waste management. The generation and disposal of waste is an intrinsic part of any developing society. A major problem in urban areas is the generation of solid waste including used disposable diapers. These items facilitate human life, but their life span is very short and the manufacturers do not anticipate its disposal; they are simply deposited in landfills, causing serious environmental pollution problems [1,2]. Nowadays, it is estimated that $90-95 \%$ of diapers used in developed countries are disposable [3]. SEMARNAT [4] reported that the total waste generation in Mexico increased from 31.4 million tons in 2001 to 42.1 million tons in 2012, a 25.4\% increase in 11 years at a growth rate of $2.3 \%$. In Mexico the composition of waste generated yearly is mostly organic matter $(38 \%)$ and potentially recyclable materials $(40 \%)[5,6]$. According to Espinosa-Valdemar et al. [7], diapers accounted for $6 \%$ of urban solid waste generated in Mexico in 1997, now this amount has increased up to $15 \%$. The typical composition of a disposable baby diaper has been described by EDANA [8] and Ng et al. [9]: fluff pulp 36.6\%, SAP 30.7\%, polypropylene $6.2 \%$, low density polyethylene $16 \%$, tape, elastic and adhesive $10.5 \%$. Disposable diapers are often seen as being a major problem, however, they can also be treated as a valuable partially biodegradable resource that can be recovered. 
Recycling of its organic content is an attractive option both, as a resource and waste management strategy [10]. At present, used diapers are generally not collected separately and are disposed of as solid municipal waste for further treatment, mainly by incineration, land filling [11,12] and, to a lesser degree, by composting [13] or anaerobic digestion [14]. Waste recycling is an important aspect of environment sustainability, on the other hand, minimizes waste products placed in landfills, promotes recovery of materials that can be reused in new productive cycles, prevents energy usage and consumption of fresh raw materials and allows to preserve natural resources and the environment for future generations. A method has been patented for the separating products such as disposable diapers containing superabsorbent polymers into their constituent parts, including a plastic component, super absorbent polymers, and cellulosic fibers, and further refinement of said constituent parts [15]. Biological treatments that valorize the cellulose content of used diapers, such as composting, and use as substrate in edible mushroom production have been investigated at laboratory $[13,16,17]$. Valorization of diapers as substrate in cultivation of $P$. ostreatus of used baby diapers and wheat straw was carried out by Espinosa-Valdemar [7].

Because of this, the need arises to propose strategies to mitigate the accumulation of disposable diapers, through the recovery and use of the superabsorbent polymer in conserving soil moisture. Recently, the diverse applications of superabsorbent polymers are still being expanded to many fields including agriculture and sealing composites, horticulture, drilling fluid additives, artificial snow, medicine, and so on [18-21]. Superabsorbents have been used to help conserve water in a variety of agriculture and horticultural applications [22-24]. The use of SAP for stabilizing soil structure resulted in increasing infiltration and reducing water use and soil erosion [25-28]. A major advantage of using SAP is its ability to make use of moisture present in soil such as clay, and make it available to the roots. SAP amended soils have better nutrient release, high nitrification, reduced microflora and bacterial content [29-31].

Hence, the aim of this study was to investigate the potential of superabsorbent polymers from used disposable diapers, an abundantly available solid waste, as a nonconventional soil moisture conditioner. The effects of ionic strength, temperature, and $\mathrm{pH}$ of the external solution on the swelling capability were investigated. The use of the hydrogel for the cultivation of bean and pumpkin was also investigated at laboratory conditions.

\section{Materials and Methods}

\section{Materials and Methods}

\subsection{Hydrogel recovery}

The wet disposable diapers were collected from the local nursery house in Ixtlahuaca - EM, Mexico. Collected disposable diapers only contained liquid waste (i.e. human urine). The diapers were first heatinactivated by autoclaving at $125^{\circ} \mathrm{C}$ for 15 minutes to eliminate pathogens. After sterilizing, the diapers were chopped up and the components were separated in two parts: cellulose and plastic. The superabsorbent polymer particles intermingled with cellulose fibers were oven dried at $60{ }^{\circ} \mathrm{C}$ for $24 \mathrm{~h}$. The dried hydrogel was retrieved by gently shaking the cellulose fibers in a plastic container in order to freeing the particles from the surrounding. Then, it was ground and sifted with an 80-mesh sieve. Resulting superabsorbent polymer powder was kept in desiccator for further use in moisture retention and soil amendment studies.

\subsection{Measurement of Swelling Ratio}

Dried hydrogel was used to determine the swelling ratio; an accurately weighed sample $(0.1 \mathrm{~g})$ was transferred to a tea bag with fine meshes (nylon screen) and then immersed entirely in distilled water 
$(100 \mathrm{~mL})$ at room temperature. At regular time-intervals, the bag was taken out from the solution, the excess of water was wiped superficially with filter paper to remove surface-bound water and the bag was weighted. The swelling ratio (Q) was obtained gravimetrically by using the following formula:

$$
\mathrm{Q}=\frac{\mathrm{W}_{\mathrm{s}}-\mathrm{W}_{\mathrm{d}}}{\mathrm{W}_{\mathrm{d}}}
$$

where $W_{d}$ and $W_{s}$ are the mass of the dry and swollen hydrogels, respectively.

\subsection{Salt Solution Absorbency Measurements}

The swelling properties of the used SAP at different ionic strength were also performed. Hydrogels were immersed in $\mathrm{NaCl}, \mathrm{Ca}\left(\mathrm{NO}_{3}\right)_{2}$ and $\mathrm{CaCl}_{2}$ solutions between 0 and $2.5 \mathrm{wt} \%$ concentrations to observe the swelling equilibrium at room temperature. The determination of water absorbency of superabsorbent polymer in different saline solutions was similar to that in distilled water.

\subsection{Effect of $\mathrm{pH}$ on Swelling Ratios of Hydrogels}

The effect of $\mathrm{pH}$ on the equilibrium swelling ratio of the hydrogel was determined in buffer media of varying $\mathrm{pH}$, ranging from 2 to 12 . The measurement of water absorbency of superabsorbent in different $\mathrm{pH}$ solutions at room temperature was according to the earlier method described for swelling measurement in distilled water. Swelling capacity of the hydrogel at each $\mathrm{pH}$ was measured according to equation (1).

\subsection{Characterization of the Superabsorbent Polymer}

The FTIR spectra of the used SAP were performed on a Perkin-Elmer Spectrum Two FourierTransform Infrared Spectrophotometer under ambient conditions. Attenuated Total Reflection (ATR) mode was used. The spectral scanned range was $4000-500 \mathrm{~cm}^{-1}$.

\subsection{Water Retention Capacity in Soil with Used SAP}

The intention of this test was to assess the effect of the hydrogel amendment on the moisture release curve of a sandy soil. The soil used in this study was taken from an agricultural area of the Ixtlahuaca region - EM, Mexico, characterized by intense vegetable production. The sample were air dried, sieved through a $2 \mathrm{~mm}$ sieve and oven dried at $70^{\circ} \mathrm{C}$ for $24 \mathrm{~h}$. Moisture release curves of soil (50 g) amended with different amounts of used SAP $(0.5,1$ and $2 \mathrm{wt} \%)$ were evaluated. The soil without the amendment of the superabsorbent polymer was used as a control. Then, the mixtures were uniformly irrigated with $25 \mathrm{~mL}$ of distilled water and exposed at room temperature. For each mixture, three replications were performed. These mixtures were weighed at certain intervals of time and the weight loss by water evaporation was registered. The water retention (WR) percentage of the soil with or without the hydrogel was calculated by the following equation:

$$
\mathrm{WR}(\%)=\frac{\mathrm{W}_{\mathrm{o}}-\mathrm{W}_{\mathrm{t}}}{\mathrm{W}_{\mathrm{t}}} 100
$$

where $W_{o}$ and $W_{\mathrm{t}}$ are the initial mixture weight, and the mixture weight at a certain time, respectively.

\subsection{Effects of Used Hydrogel on Germination Seeds}

The purpose of this study was to explore the possible application of used SAP as water reservoir in agriculture, its direct effect on the cultivation of bean (Phaseolus vulgaris L.) and pumpkin (C. pepo) obtained from a commercial tree nursery in Ixtlahuaca - EM, Mexico, which were used in the essays applied in lab conditions [32]. These species were chosen because they are grown in almost all Mexican territory, are found in a large range of ecological conditions and have economic importance, moreover 
they may be grown and consumed locally. These seedlings establish best in soils with adequate moisture. The used SAP was mixed at the rate of $0.5,1$ and $2 \%$ in dried soil. Then, $200 \mathrm{~g}$ of each of the sandy soil mixtures were filled in plastic pots ( $300 \mathrm{~mL}$ volume) with a filter paper placed at the bottom with a small hole. The sandy soil without the amendment of the hydrogel was used as a control. Four seeds each of bean and pumpkin were sown in triplicate pots for each of the soil and hydrogel combinations were used. The pots were then placed in plastic trays containing tap water at a depth of $6 \mathrm{~cm}$ and watered to ensure saturation. All the pots were placed in a dark room at the constant temperature $\left(25^{\circ} \mathrm{C}\right)$. After two weeks, germinated seeds were counted and recorded. Emergence of shoot was taken as an indicator of seed germination. No water was applied except the initial saturation of the pots. When the signs of wilting of seedlings appeared for the first time, the test was finalized. The plant shoots were harvested at ground level and shoot length and fresh weight were recorded. The germination percentage of the seeds was calculated as:

$$
\text { Germination porcentage }(\%)=\frac{\text { Amount of germinating seeds }}{\text { Total seeds }} \times 100
$$

\section{Results and Discussion}

\subsection{Swelling Behavior of the Used SAP}

Absorption capacity in grams of distilled water per gram of dry used superabsorbent polymer at different time intervals was measured. Initially, the rate of water uptake is very fast, and then it begins to level off. As observed in Figure 1, the swelling ability of the used hydrogel reaches its maximum value at $189 \mathrm{~g} \cdot \mathrm{g}^{-1}$ in approximately $30 \mathrm{~min}$. A time length of 30 minutes was thus considered as a reasonable and acceptable duration for complete hydrogel swelling, taking into account the possibilities of its applications in the agricultural field.

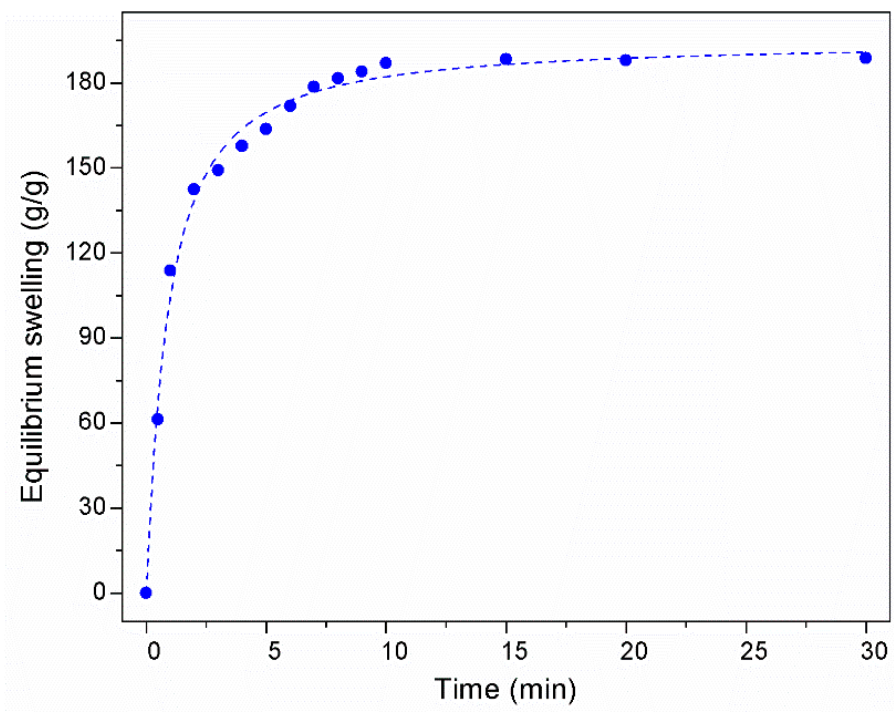

Figure 1. Swelling ratio as function of time for used SAP at $25^{\circ} \mathrm{C}$.

According to the above results, may be attributed to the fact that superabsorbent polymer possess many hydrophilic groups, appropriate crosslinking degree and appropriate three-dimensional network structure which generates osmotic pressure [25]. 


\subsection{Effect of $p H$ on Swelling Ratios of Hydrogels}

The pH sensitivity of SAP polymer was studied by observing the equilibrium swelling (ultimate water absorption) at various $\mathrm{pH}$ values by using buffer solutions (Figure 2). In acidic media, the most of carboxylate groups are protonated. This causes a decrease repulsion of anionic groups, which leads to a decrease in swelling ratio. In neutral medium, the ionic strength is smaller than that in basic media, so provides higher swelling capacity [33]. This is because the superabsorbent is anionic-type superabsorbent polymer, which contain a majority of hydrophilic groups, and which play an important role in swelling behavior and result in water absorbency changes through different interaction species in various $\mathrm{pH}$ solution. When the $\mathrm{pH}$ is 12 , the increased ionic strength of the swelling medium causes the rapid decreases of ion osmotic pressure and ultimately reduces the equilibrium swelling capacity. It is worthy to point out that the hydrogel can keep high swelling capacity in distilled water at $\mathrm{pH}<10$, which is caused by the buffer action of $-\mathrm{COOH}$ and $-\mathrm{COO}-$ groups and is very advantageous for the application of superabsorbent in agriculture. Similar conclusions could also be found in other works [34].

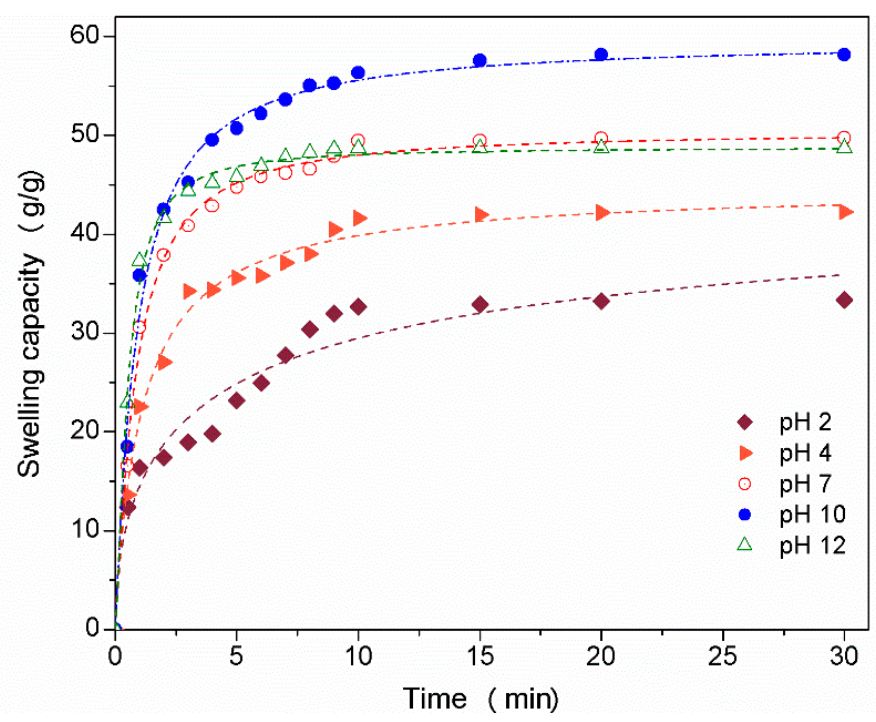

Figure 2. Water retention capacity at different values of $\mathrm{pH}$.

\subsection{Effect of Salt Solution on the Swelling Ratio of Hydrogel}

It is more important to know the swelling capacity of a superabsorbent polymer when it contacts with various saline solutions considering its practical applications such as water release systems in agriculture. The equilibrium swelling of used SAP in different concentrations of $\mathrm{NaCl}, \mathrm{Ca}\left(\mathrm{NO}_{3}\right)_{2}$ and $\mathrm{CaCl}_{2}$ were investigated, as shown in Figure 3. When the SAP is placed in water, the maximum osmotic pressure is developed, and then the maximum swelling is achieved. The swelling ability of the superabsorbent in the three salts in aqueous medium was significantly decreased compared to the values measured in distilled water. This phenomenon, commonly observed in the swelling of all ionic hydrogels, is often attributed to a screening effect of the additional cations causing a non-efficient anion-anion electrostatic repulsion. This is also attributed to a decreased osmotic pressure difference between the SAP network and the external solution resulting from the difference in the mobile ion concentration between the gel and aqueous phases decrease and, consequently, the absorbency amounts are diminished. This finding is consistent with previous studies [35], the decrease in swelling is strongly dependent on the type and concentration of salt added to the swelling medium. 


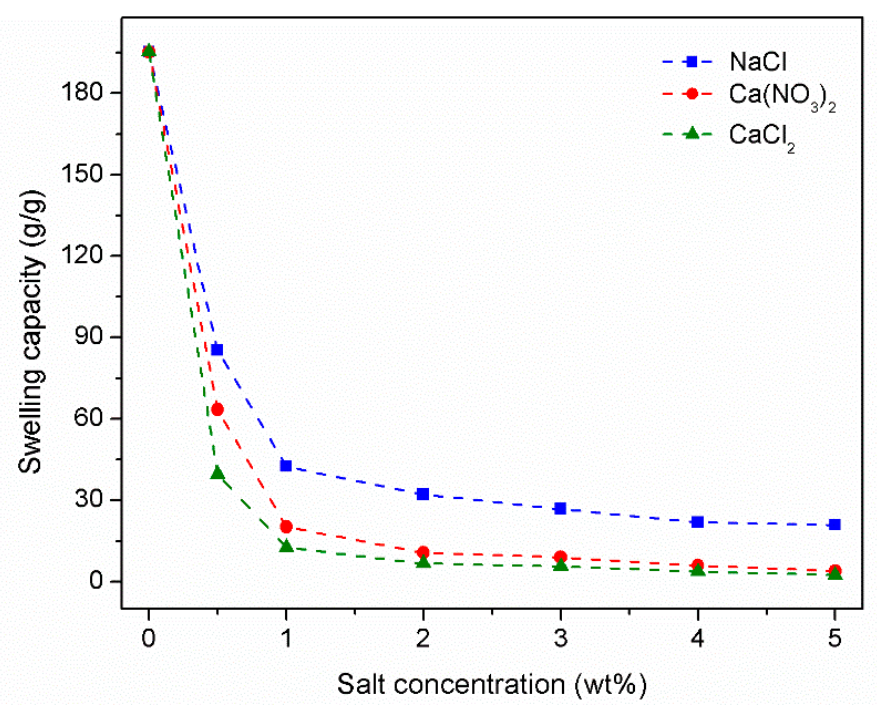

Figure 3. Swelling ratios of superabsorbent in different saline solutions.

\subsection{Effect of Temperature on Swelling Ratio of Hydrogel}

The effect of environmental temperature on equilibrium swelling of SAP was determined in the range of temperatures between $25-50{ }^{\circ} \mathrm{C}$. Hydrogel exhibits significant continuous changes in water content as a function of temperature [36,37]. It can be seen from Figure 4, the swelling ratio increase with temperature. The results given in Figure 4 may be explained by the fact that at $50{ }^{\circ} \mathrm{C}$, it is more thermodynamically favorable for water molecules to form hydrogen bonds with polar groups on the polymer chains, causing the hydrogel to be in swollen state. With increasing temperature, the mobility of the hydrogel chains increases effectively, and consequently the water absorption capacity of the SAP is increased. At above $50{ }^{\circ} \mathrm{C}$ the swelling is drastically reduced. Therefore, the breakage of hydrogen bonds between the water molecules and network chains causes decrease in swelling ratio of the hydrogel.

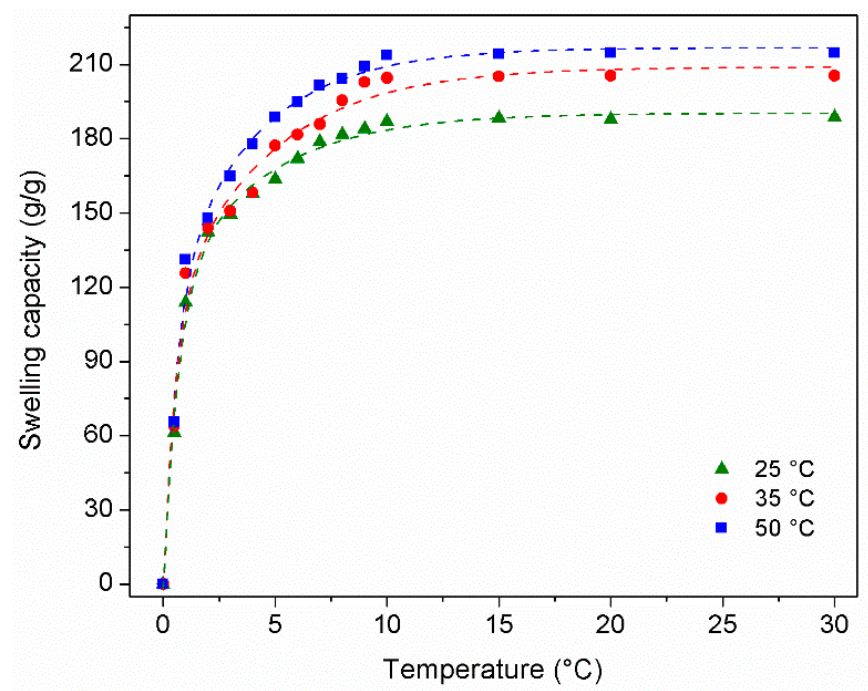

Figure 4. Water uptake capacity as a function of temperature.

\subsection{FTIR analysis}


The infrared spectroscopy was used to determine the type of bonds present in the used SAP as shown in Figure 5. In the spectra, absorption peaks characteristic of the expected functional groups are visible, in general agreement with published data $[19,20,23,24]$. The broad absorption band at $3260 \mathrm{~cm}^{-1}$ is ascribed to hydrogen bond -OH stretching vibration. It can be observed that the medium absorption peak at $2932 \mathrm{~cm}^{-1}$ represents symmetric and asymmetric $\mathrm{C}-\mathrm{H}$ stretching vibration of aliphatic structures. The peak at $1402 \mathrm{~cm}^{-1}$ was due to bending vibration of $\mathrm{C}-\mathrm{H}$ of methyl group. The absorption bands at 1552 and $1052 \mathrm{~cm}^{-1}$ are attributed to the appearance of $-\mathrm{C}=\mathrm{O}$ of bonded conjugated ketones, carboxylic acids and esters. Based on the above analysis, the presence of various functional groups suggests that the employed SAP could have the possibility to be used as a soil amendment for improving moisture.

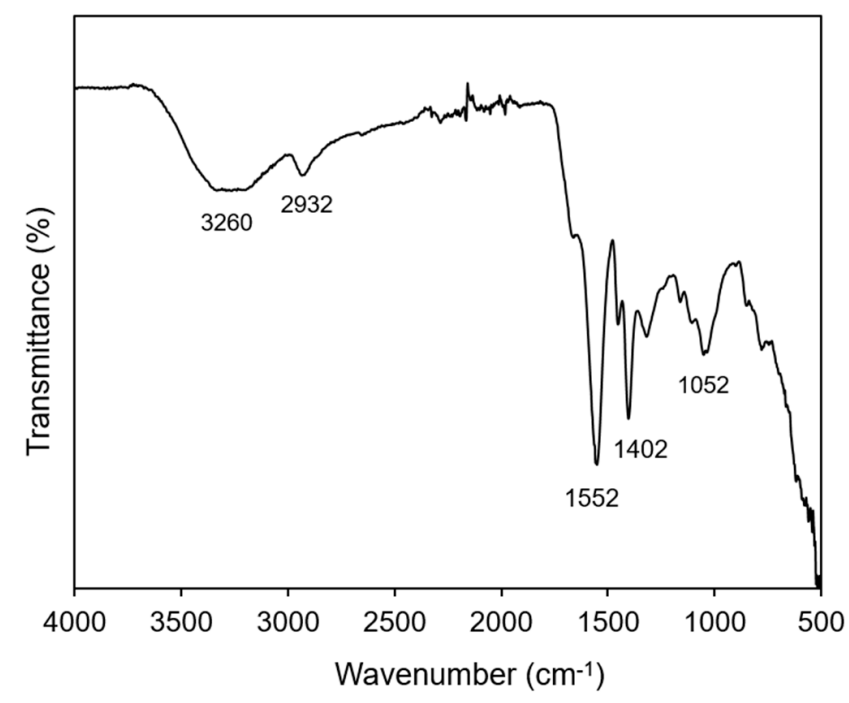

Figure 5. FTIR of used superabsorbent polymer.

\subsection{Water Retention Behavior in Soil-Superabsorbent Polymer}

For agricultural use it is essential to evaluate the ability of the superabsorbent polymer to retain water in the soil for vegetation growth. Liquid water ensures the feeding of plants with nutritional elements, which increases the growth quality of plants. Figure 6 shows the water retention of soil mixed with SAP and soil without the SAP. The percentage of water retained by the soil, monitored for several days after an initial irrigation of a soil sample with different amounts of hidrogel was indeed significantly affected by the presence of the hydrogel, with higher water contents detected at selected time points, when increasing the hydrogel concentration. The rate of water loss increased with increased incubation time. The value of $100 \%$ corresponds to the initial weight of soil-hidrogel-water mixtures. It can be observed from Figure 6 that the amount of water in the control soil (without SAP) reaches zero after 12 days. After the addition of small hydrogel amounts (up to a maximum of $2 \%$ ), the time length through which the soil remained humid almost triplicated, with respect to the soil without hydrogel. It is clear that soil mixed with SAP can hold more water than soil without SAP. When soil is treated with $\mathrm{SAP}$, its water retention properties are related to both porosity and the SAP's water absorbency. These results suggested that the adding of hydrogels into soil could obviously improve the water-retention capacity of soil and lessen the amount of water evaporation [35,38,39]. The trends of the curves suggest that the SAP improved the water retention properties of the treated soil during the early period. Similar effects of hydrogels on loamy soil water holding properties by Akhter et al. [40], and in sandy soils by Dorraji et al. [41] have been investigated. 


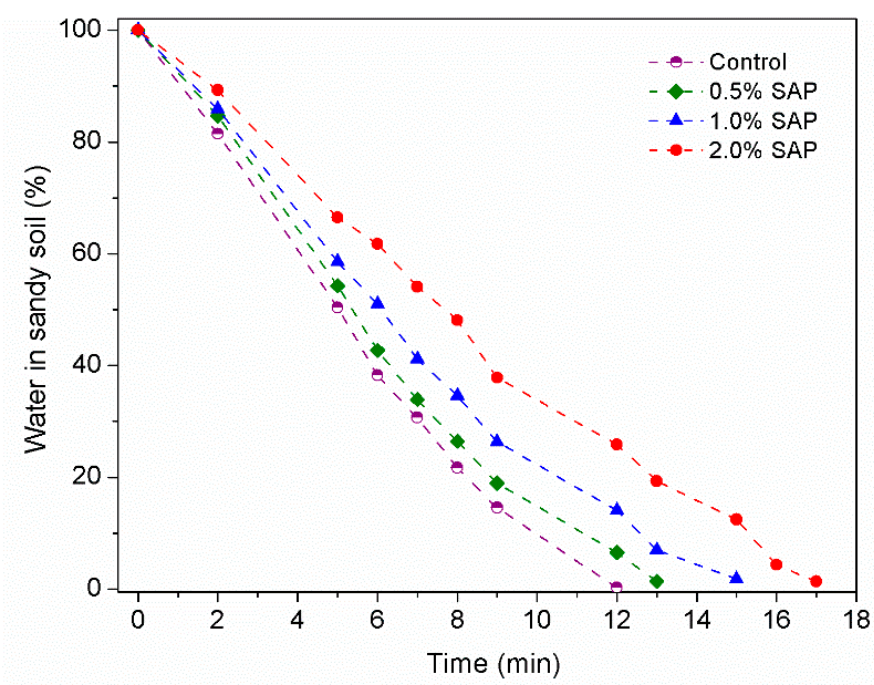

Figure 6. Moisture retention capacity in soil (control) and in mixtures soils with increasing amount of SAP $(0.5,1$ and $2 \mathrm{wt} \%)$.

\subsection{Seed germination and seedling growth}

Seedling growth of both species, bean and pumpkin, was enhanced by the addition of used SAP in the sandy soil. Seed germination was considerably higher in $0.5-2.0 \%$ of SAP amended soils as compared to the control. As shown in Figure 7, the influence of used SAP on seed germination is evident; the controlled and sustained release of water allows plants to survive for several days without the need of further irrigation. As observed, the overall seed germination percentage of bean was slightly higher than pumpkin. The presence of SAP in the sandy soil drastically altered the height of the plants than of the not amended control with increments of 30, 127 and 399\%, respectively, with $0.5,1$ and $2 \%$ of hydrogel in the case of bean (Phaseolus vulgaris L.), while for the pumpkin (C. pepo) the increases were 16, 59 and $178 \%$, corresponding to $0.5,1$ and $2 \%$ of hydrogel in soil.

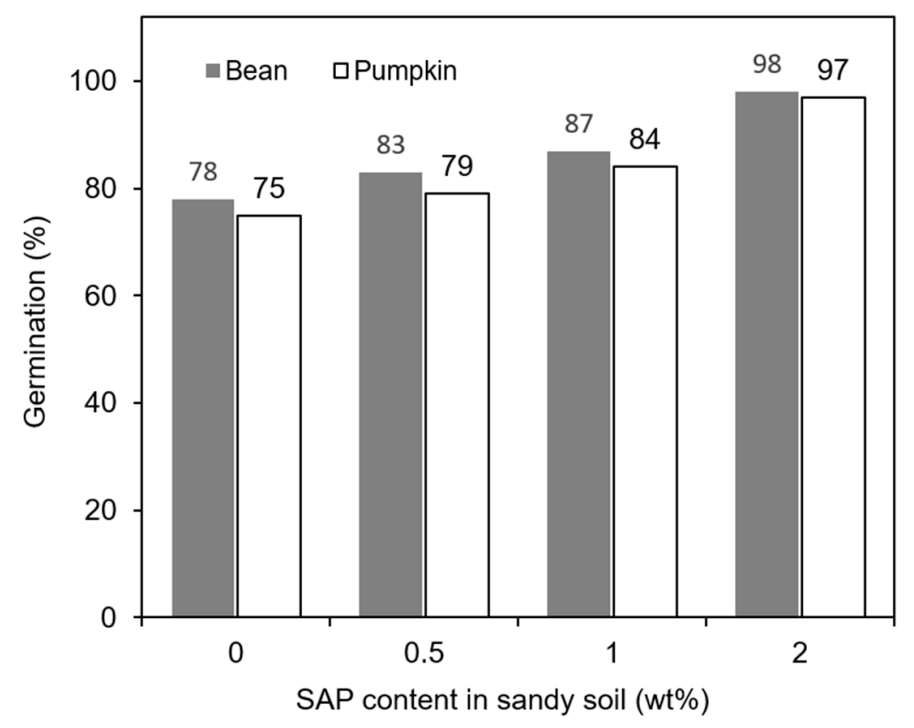

Figure 7. Effect of SAP content in soil. 
The enhancement in soil moisture retention and improvement in seed germination and seedling growth as a result of superabsorbent hydrogel amendments has been reported previously [39,42]. The quantity of this increment depends on the quantity of hydrophilic polymer used [41]. The proposed SAP enhanced the moisture retention of soil and plant available water significantly, thereby slowing down the rate of moisture loss, due to which a delay of aproximately 20-23 days in wilting point was observed. Such a delay in wilting point reduces the water requirement of plants. The germination energy of the seeds in soil with incorporation of hydrophilic polymer was obviously higher and denser than that of the seeds in soil without SAPs (Table 1 and Table 2). This is likely because the SAPs not only can absorb large amounts of water but also have good water retention capability, which supplies enough water to promote plant growth. The root and shoot biomass weights of both species was generally higher in SAP amended soil. Increase in plant growth may also be due to increased nutrient retention in amended soil, although no fertilizer was applied to plants in the present study. The positive effect of the hydrogel usage for the plant survival and growth of the plants has been reported in various studies [42,43].

Table 1. Effect of different amount of SAP (wt \%) on seed germination and seedling growth (16 days) of bean (Phaseolus vulgaris L.) in sandy soil.

\begin{tabular}{ccccc}
\hline $\begin{array}{c}\text { SAP content } \\
\mathbf{( \% )}\end{array}$ & $\begin{array}{c}\text { Height of the } \\
\text { plant } \mathbf{( c m})\end{array}$ & $\begin{array}{c}\text { Length of } \\
\text { the root }(\mathbf{c m})\end{array}$ & $\begin{array}{c}\text { Weight of } \\
\text { fresh plant }(\mathbf{g})\end{array}$ & $\begin{array}{c}\text { Dry weight } \\
\text { of plant } \mathbf{( g )}\end{array}$ \\
\hline 0 (control) & $12.8 \pm 0.51$ & $9.2 \pm 0.65$ & 1.8716 & 0.2209 \\
0.5 & $16.7 \pm 0.71$ & $10.1 \pm 0.64$ & 2.1278 & 0.2311 \\
1.0 & $22.3 \pm 0.65$ & $10.8 \pm 81$ & 2.3165 & 0.2401 \\
2.0 & $28.4 \pm 0.76$ & $11.3 \pm 0.85$ & 2.5104 & 0.2503 \\
\hline
\end{tabular}

The results are means of three replicates; \pm , standard deviation.

Table 2. Effect of different amount of SAP (wt $\%$ ) on seed germination and seedling growth (15 days) of pumpkin (C. pepo).

\begin{tabular}{ccccc}
\hline $\begin{array}{c}\text { SAP } \\
\text { content }(\%)\end{array}$ & $\begin{array}{c}\text { Height of the } \\
\text { plant }(\mathbf{c m})\end{array}$ & $\begin{array}{c}\text { Length of } \\
\text { the root }(\mathbf{c m})\end{array}$ & $\begin{array}{c}\text { Weight of } \\
\text { fresh plant }(\mathbf{g})\end{array}$ & $\begin{array}{c}\text { Dry weight } \\
\text { of plant }(\mathbf{g})\end{array}$ \\
\hline 0 (control) & $9.6 \pm 0.71$ & $9.4 \pm 0.68$ & 0.7650 & 0.0652 \\
0.5 & $11.9 \pm 0.74$ & $10.2 \pm 0.66$ & 1.1371 & 0.0858 \\
1.0 & $13.2 \pm 0.62$ & $11.7 \pm 0.71$ & 1.4138 & 0.1227 \\
2.0 & $16.5 \pm 0.83$ & $13.3 \pm 0.81$ & 1.6021 & 0.1533 \\
\hline
\end{tabular}

The results are means of three replicates; \pm , standard deviation.

Although further investigations should be performed to assess the hydrogel degradation chemistry and kinetics in the soil, the preliminary results of this lab study show promise for the possible use of recycled hydrogels as water reservoir in agriculture. With regard to the hydrogel degradation, analyses that are currently in progress seem to suggest that the hydrogel degradation occurs over a period of approximately 6 months [30], without significantly altering the soil chemistry.

\section{Conclusions}

The superabsorbent polymer evaluated in this study showed the positive properties generally reported for others traditional hydrogels. The proposed SAP exhibited a high swelling ratio of $189 \mathrm{~g} \cdot \mathrm{g}^{-1}$ of dry SAP. The results showed that, in salt solution, swelling ratio decreased with increasing ionic strength. The hydrogel exhibited a thermal and $\mathrm{pH}$ swelling behavior. Application of used 
superabsorbent polymer markedly improved retention capacity of soil for a longer time compared with control conditions. The use of the hydrogel from disposable diapers as water reservoir in the seed germination of bean and pumpkin in lab conditions was found to be advantageous and suitable for the sustained release of water to the soil and to the plant roots. These findings suggest that using SAP as soil conditioner will be useful for increased soil available water and consequently plant.

Acknowledgments: The authors would like to thank the financial support of the Tecnológico de Estudios Superiores de Jocotitlán in the development of this Research project. Carmen Miranda assisted in the preparation of this manuscript.

Author Contributions: Raymundo Sánchez-Orozco conceived, designed the experiments and wrote the paper; Beatriz Timoteo-Cruz performed and analyzed the data experiments. All other authors contributed significantly through their guidance and support during the experiments and the writing process.

Conflicts of Interest: The authors declare no conflict of interest.

\section{References}

1. Cordella, M.; Bauer, I.; Lehmann, A.; Schulz, M.; Wolf, O. Evolution of disposable baby diapers in Europe : life cycle assessment of environmental impacts and identi fi cation of key areas of improvement. J. Clean. Prod. 2015, 95, 322-331, DOI: 10.1016/j.jclepro.2015.02.040

2. Qu, G.; de Varennes, A. Use of hydrophilic polymers from diapers to aid the establishment of Spergularia purpurea in a mine soil. J. Hazard. Mater. 2010, 178, 956-62, DOI: 10.1016/j.jhazmat.2010.02.031.

3. Kosemund, K.; Schlatter, H.; Ochsenhirt, J. L.; Krause, E. L.; Marsman, D. S.; Erasala, G. N. Safety evaluation of superabsorbent baby diapers. Regul. Toxicol. Pharmacol. 2009, 53, 81-89, DOI: 10.1016/j.yrtph.2008.10.005.

4. SEMARNAT. Generación estimada de residuos sólidos urbanos por entidad federativa (miles de toneladas). Secretaría de Medio Ambiente y Recursos Naturales, México, 2012. Available online: http://apps1.semarnat.gob.mx/dgeia/compendio_2013/archivos/01_rsu/D3_RSM01_04.pdf (accessed on 13 January 2017).

5. Espinosa-Valdemar, R. M.; Sotelo-Navarro, P. X.; Quecholac-Piña, X.; Beltrán-Villavicencio, M.; Ojeda-Benítez, S.; Vázquez-Morillas, A. Biological recycling of used baby diapers in a small-scale composting system. Resour. Conserv. Recycl. 2014, 87, 153-157, DOI: 10.1016/j.resconrec.2014.03.015.

6. SEMARNAT. Diagnóstico básico para la gestión integral de los residuos. Secretaría de Medio Ambiente y Recursos Naturales, México, $2012 . \quad$ Available online: http://www.inecc.gob.mx/descargas/dgcenica/diagnostico_basico_extenso_2012.pdf (accessed on 20 January 2017).

7. Espinosa-Valdemar, R.M.; Turpin-Marion, S.; Delfín-Alcalá, I.; Vazquez-Morillas, A. Disposable diapers biodegradation by the fungus Pleurotus Ostreatus. Waste Manag. 2011, 31, 1683-1688, doi:10.1016/j.wasman.2011.03.007.

8. EDANA. Sustainability Report 2007-2008. Absorbent Hygiene Products. Brussels, Belgium, 2007. Available online: http://www.edana.org/docs/default-source/default-document-library/sustainability-report-2007-2008absorbent-hygiene-products.pdf?sfvrsn=2 (accessed on 3 February 2017).

9. Ng, F. S.-F.; Muthu, S. S.; Li, Y.; Hui, P. C.-L. A critical review on life cycle assessment studies of diapers. Crit. Rev. Environ. Sci. Technol. 2012, 43, 1795-1822, DOI: 10.1080/10643389.2012.671746.

10. Sannino, A.; Demitri, C.; Madaghiele, M. Biodegradable cellulose-based hydrogels: Design and applications. Materials 2009, 2, 353-373, DOI: 10.3390/ma2020353. 
11. Mirabella, N.; Castellani, V.; Sala, S. Life cycle assessment of bio-based products: A disposable diaper case study. Int. J. Life Cycle Assess. 2013, 18, 1036-1047, DOI: 10.1007/s11367-013-0556-6.

12. Oh, T.-K.; Shinogi, Y. Characterization of the pyrolytic solid derived from used disposable diapers. Environ. Technol. 2013, 34, 3153-60, DOI: 10.1080/09593330.2013.808240.

13. Colón, J.; Mestre-Montserrat, M.; Puig-Ventosa, I.; Sánchez, A. Performance of compostable baby used diapers in the composting process with the organic fraction of municipal solid waste. Waste Manag. 2013, 33, 1097-1103, DOI: 10.1016/j.wasman.2013.01.018.

14. Torrijos, M.; Sousbie, P.; Rouez, M.; Lemunier, M.; Lessard, Y.; Galtier, L.; Simao, A.; Steyer, J. P. Treatment of the biodegradable fraction of used disposable diapers by co-digestion with waste activated sludge. Waste Manag. 2014, 34, 669-675, DOI: 10.1016/j.wasman.2013.11.009.

15. Grimes, D. B. Separation of materials comprising super absorbent polymers using reduced water. US 8,177,151 B2, May 15, 2012.

16. Colón, J.; Ruggieri, L.; Sánchez, A.; González, A.; Puig, I. Possibilities of composting disposable diapers with municipal solid wastes. Waste Manag. Res. 2010, 29, 249-259, DOI: 10.1177/0734242X10364684.

17. Espinosa-Valdemar, R.M.; Vázquez-Morillas, A.; Ojeda-Benítez, S.; Arango-Escorcia, G.; Cabrera-Elizalde, S.; Quecholac-Piña, X.; Velasco-Pérez, M.; Sotelo-Navarro, P.X. Assessment of gardening wastes as a co-substrate for diapers degradation by the fungus Pleurotus ostreatus. Sustainability 2015, 7, 6033-6045., DOI: $10.3390 /$ su7056033.

18. Raafat, A. I.; Eid, M.; El-arnaouty, M. B. Radiation synthesis of superabsorbent CMC based hydrogels for agriculture applications. Nucl. Inst. Methods Phys. Res. B 2012, 283, 71-76, DOI: 10.1016/j.nimb.2012.04.011.

19. Zhong, K.; Lin, Z.; Zheng, X.; Jiang, G.; Fang, Y.; Mao, X.; Liao, Z. Starch derivative-based superabsorbent with integration of water-retaining and controlled-release fertilizers. Carbohydr. Polym. 2013, 92, 1367-1376, DOI: 10.1016/j.carbpol.2012.10.030.

20. Rosa, F.; Casquilho, M. Effect of synthesis parameters and of temperature of swelling on water absorption by a superabsorbent polymer. Fuel Process. Technol. 2012, 103, 174-177, DOI: 10.1016/j.fuproc.2011.09.004.

21. Nnadi, F.; Brave, C. Environmentally friendly superabsorbent polymers for water conservation in agricultural lands. J. Soil Environ. Manag. 2011, 2, 206-211.

22. Guilherme, M. R.; Aouada, F. A.; Fajardo, A. R.; Martins, A. F.; Paulino, A. T.; Davi, M. F. T.; Rubira, A. F.; Muniz, E. C. Superabsorbent hydrogels based on polysaccharides for application in agriculture as soil conditioner and nutrient carrier: A review. Eur. Polym. J. 2015, 72, 365-385, DOI: 10.1016/j.eurpolymj.2015.04.017.

23. Qiao, D.; Liu, H.; Yu, L.; Bao, X.; Simon, G. P.; Petinakis, E.; Chen, L. Preparation and characterization of slowrelease fertilizer encapsulated by starch-based superabsorbent polymer. Carbohydr. Polym. 2016, 147, 146-154, DOI: 10.1016/j.carbpol.2016.04.010.

24. Senna, A. M.; Braga, J.; Mauro, J.; Botaro, V. R. Synthesis , characterization and application of hydrogel derived from cellulose acetate as a substrate for slow-release NPK fertilizer and water retention in soil. J. Environ. Chem. Eng. 2015, 3, 996-1002, DOI: 10.1016/j.jece.2015.03.008.

25. Gao, L.; Wang, S.; Zhao, X. Synthesis and characterization of agricultural controllable humic acid superabsorbent. J. Environ. Sci. 2013, 25, S69-S76, DOI: 10.1016/S1001-0742(14)60629-X.

26. Essawy, H. A.; Ghazy, M. B. M.; El-hai, F. A.; Mohamed, M. F. Superabsorbent hydrogels via graft 
polymerization of acrylic acid from chitosan-cellulose hybrid and their potential in controlled release of soil nutrients. Int. J. Biol. Macromol. 2016, 89, 144-151, DOI: 10.1016/j.ijbiomac.2016.04.071.

27. Ahmed, E. M. Hydrogel: Preparation, characterization, and applications: A review. J. Adv. Res. 2015, 6, $105-121$. DOI: 10.1016/j.jare.2013.07.006.

28. Li, X.; He, J.; Hughes, J. M.; Liu, Y.; Zheng, Y. Effects of super-absorbent polymers on a soil - wheat (Triticum aestivum L.) system in the field. Appl. Soil Ecol. 2014, 73, 58-63, DOI: 10.1016/j.apsoil.2013.08.005.

29. Eneji, A. E.; Islam, R.; An, P.; Amalu, U. C. Nitrate retention and physiological adjustment of maize to soil amendment with superabsorbent polymers. J. Clean Prod. 2013, 52, 474-480, DOI: 10.1016/j.jclepro.2013.02.027.

30. Demitri, C.; Scalera, F.; Madaghiele, M.; Sannino, A.; Maffezzoli, A. Potential of cellulose-based superabsorbent hydrogels as water reservoir in agriculture. Int. J. Polym. Sci. 2013, 2013, 1-6, DOI: 10.1155/2013/435073.

31. Mukerabigwi, J. F.; Wang, Q.; Ma, X.; Liu, M. Urea fertilizer coated with biodegradable polymers and diatomite for slow release and water retention. J. Coatings Technol. Res. 2015, 12, 1085-1094, DOI: 10.1007/s11998-015-97032.

32. Hong, S. H.; Lee, E. Y. Restoration of eroded coastal sand dunes using plant and soil- conditioner mixture. Int. Biodeterior. Biodegradation 2016, 113, 161-168, DOI: 10.1016/j.ibiod.2016.04.021.

33. Gawande, N.; Mungray, A. A. Superabsorbent polymer ( SAP ) hydrogels for protein enrichment. Sep. Purif. Technol. 2015, 150, 86-94, DOI: 10.1016/j.seppur.2015.04.024.

34. Cheng, W.-M.; Hu, X.-M.; Wang, D.-M.; Liu, G.-H. Preparation and characteristics of corn straw-Co-AMPS-CoAA superabsorbent hydrogel. Polymers 2015, 7, 2431-2445, DOI: 10.3390/polym7111522.

35. Li, X.; Li, Q.; Su, Y.; Yue, Q.; Gao, B.; Su, Y. A novel wheat straw cellulose-based semi-IPNs superabsorbent with integration of water-retaining and controlled-release fertilizers. J. Taiwan Inst. Chem. Eng. 2015, 55, 170179, DOI: 10.1016/j.jtice.2015.04.022.

36. Liang, R.; Liu, M.; Wu, L. Controlled release NPK compound fertilizer with the function of water retention. React. Funct. Polym. 2007, 67, 769-779, DOI: 10.1016/j.reactfunctpolym.2006.12.007.

37. Zhang, X.; Wang, X.; Li, L.; Zhang, S.; Wu, R. Preparation and swelling behaviors of a high temperature resistant superabsorbent using tetraallylammonium chloride as crosslinking agent. React. Funct. Polym. 2015, 87, 15-21, DOI: 10.1016/j.reactfunctpolym.2014.12.006.

38. Liao, R.; Wu, W.; Ren, S.; Yang, P. Effects of superabsorbent polymers on the hydraulic parameters and water retention properties of soil. J. Nanomater. 2016, 2016, 1-11, DOI: 10.1155/2016/5403976

39. Shahid, S. A.; Qidwai, A. A.; Anwar, F.; Ullah, I.; Rashid, U. Improvement in the water retention characteristics of sandy loam soil using a newly synthesized poly(acrylamide-co-acrylic acid)/AlZnFe2O4 superabsorbent hydrogel nanocomposite material. Molecules 2012, 9397-9412, DOI: 10.3390/molecules17089397.

40. Akhter, J.; Mahmood, K.; Malik, K. A.; Mardan, A.; Ahmad, M.; Iqbal, M. M. Effects of hydrogel amendment on water storage of sandy loam and loam soils and seedling growth of barley, wheat and chickpea. Plant Soil. and Environ. 2004, 50, 463-469.

41. Dorraji, S. S.; Golchin, A.; Ahmadi, S. The effects of hydrophilic polymer and soil salinity on corn growth in sandy and loamy soils. Clean - Soil, Air, Water 2010, 38, 584-591, DOI: 10.1002/clen.201000017.

42. Orikiriza, L. J. B.; Agaba, H.; Eilu, G.; Kabasa, J. D.; Worbes, M. Effects of hydrogels on tree seedling performance in temperate soils before and after water stress. J. Environ. Prot. 2013, 4, 713-721, DOI: 10.4236/jep.2013.47082. 
43. Agaba, H.; Orikiriza, L. J. B.; Esegu, J. F. O.; Obua, J.; Kabasa, J. D.; Hüttermann, A. Effects of hydrogel amendment to different soils on plant available water and survival of trees under drought conditions. Clean Soil, Air, Water 2010, 38, 328-335, DOI: 10.1002/clen.200900245.

(C) 2017 by the authors. Licensee Preprints, Basel, Switzerland. This article is an open access article distributed under the terms and conditions of the Creative Commons by Attribution (CC-BY) license (http://creativecommons.org/licenses/by/4.0/). 